\title{
Epidemiology and factors associated with amoebic liver abscess in northern Sri Lanka
}

\author{
Selvam Kannathasan ${ }^{1 *}$ (D), Arumugam Murugananthan', Thirunavukarasu Kumanan², Nilanthi Renuka de Silva ${ }^{3}$,
} Nadarajah Rajeshkannan ${ }^{4}$, Rashidul Haque ${ }^{5}$ and Devika Iddawela ${ }^{6}$

\begin{abstract}
Background: Clinically diagnosed amoebic liver abscess (ALA) caused by Entamoeba histolytica has been an important public health problem in Jaffna district, northern Sri Lanka for last three decades. In order to draw up a control strategy for elimination of this condition, knowledge of its epidemiology and factors associated with this condition in the local context is vital.
\end{abstract}

Methods: All clinically diagnosed ALA patients admitted to the Teaching Hospital, Jaffna during the study period were included in the study and the data were collected using an interviewer administered questionnaire. One hundred blood samples from randomly selected toddy (a local alcoholic drink consisting of the fermented sap of the Palmyrah palm) consumers and 200 toddy samples were collected. Toddy samples were cultured in Robinson's medium to establish the presence of Entamoeba histolytica in the sample. Climatic data and the total toddy sales in the district were obtained from the Meteorological and Excise Departments respectively. A sub group of randomly selected 100 patients were compared with 100 toddy consumers who were negative for E. histolytica antibody to explore the potential risk factors.

Results: Between July 2012 and July 2015, 346 of 367 ALA patients were enrolled in this study. Almost all patients (98. $6 \%$ ) were males with a history of heavy consumption of alcohol (100\%). Almost all (94.2\%) were within the age group 31-50 years. None of the cultured toddy samples grew E. histolytica. The monthly incidence of disease peaked in the dry season, matching the total toddy sales in the district. Age, type of alcohol and frequency of drinking were identified as potential risk factors whereas frequency of alcohol consumption and type of alcohol (consuming toddy and arrack) were identified as the independent risk factors. Moreover, the knowledge, attitude and practices towards ALA were poor among participants and the control group.

Conclusions: Though the number of cases has declined in recent years, ALA still remains as an important public health problem in Jaffna district. The transmission route of E. histolytica leading to ALA has to be further explored. Moreover, greater awareness among the public who are at risk would be beneficial in order to eliminate the disease.

Keywords: Amoebic liver abscess, Amoebiasis, Entamoeba histolytica, Sri Lanka

\section{Background}

Amoebiasis, a parasitic condition, caused by Entamoeba histolytica, affects at least 50 million people globally and killing 100,000 individuals every year [1]. The most common extra intestinal manifestation of invasive amoebiasis is the Amoebic Liver Abscess (ALA), apart from its classical amoebic colitis. In the recent past, clinically diagnosed

\footnotetext{
* Correspondence: selvamkannathasan@gmail.com

'Department of Pathology, Faculty of Medicine, University of Jaffna, Jaffna, Sri Lanka

Full list of author information is available at the end of the article
}

ALA has been one of the two most important parasitological public health problems (second only to malaria) in Jaffna, northern Sri Lanka [2-6]. Recently, we have confirmed that the cases of ALA were amoebic in origin [6]. Interestingly, it was observed by us $[4,5]$ and few others from Sri Lanka and elsewhere [3, 7-9] that most of the ALA patients had the history of consuming local alcoholic beverage, toddy (a local alcoholic drink consisting of the fermented sap of the palmyrah palm). Moreover, Hai et al. were able to demonstrate Entamoeba histolytica in $12.5 \%$ of cultured toddy in vitro [9]. 
In addition to the consumption of alcohol, poor living conditions, overcrowding, unhygienic practices [10], age, sex [11] and men who have sex with men [12] were identified as the major risk factors for ALA.

Although malaria has been under control in Jaffna district since 2002, cases of clinically diagnosed ALA have been continuously reported to the Teaching Hospital (TH), Jaffna. In order to draw up a control strategy for elimination of the condition, knowledge about disease burden, its local epidemiology, associated risk factors, seasonality of the condition in the local context and the knowledge, attitude and practice (KAP) towards the disease among those who are at risk, is essential.

Therefore, this study was carried out to examine the above factors in order to propose a control plan which is expected to prevent or minimize the transmission of Entamoeba histolytica in Jaffna district, northern Sri Lanka.

\section{Methods}

\section{Study design and the study period}

A longitudinal study was conducted among the clinically diagnosed ALA patients admitted to Jaffna TH, during the period from July 2012 to July 2015. Clinicians arrived at a clinical diagnosis mainly based on the patient's history, clinical features and other investigations such as haematological parameters and mainly with the aid of ultrasonography. Out of 367 patients admitted during the study period, 346 consented for study (response rate - 94\%). Further, to explore the associated factors, a sub study was conducted by comparing 100 randomlyselected, male patients with sex-matched controls of toddy consumers who were negative for $E$. histolytica antibody.

\section{Collection of epidemiological information and the} knowledge, attitude and practice towards ALA data Relevant data were collected from the patients and the control group using a pretested interviewer administered questionnaire. The questionnaire contained both open and close ended questions in the native language (Tamil). The questionnaire included the following information, a) general socio demographic data b) personal hygienic practices and alcohol consumption history and c) the knowledge, attitude and practices in relation to ALA.

\section{Collection of toddy samples}

Five taverns were selected based on where most of the patients consumed toddy. Twenty toddy samples (250 $\mathrm{ml}$ each) from each tavern were collected on different days of the month. Further, 100 samples of fresh toddy $(250 \mathrm{ml}$ each), were also obtained just after collection from the palmyrah tree, at each particular location. All samples were brought to the laboratory and filtered through a sieve, centrifuged at the rate of $2500 \mathrm{rpm}$ for $10 \mathrm{~min}$ and the supernatant was discarded. The pellet was used for further investigation.

\section{Monthly toddy sales in Jaffna district during the study period}

Records of monthly toddy sales (in bottles) in the entire district throughout the study period was obtained from the Excise Department, Jaffna.

\section{Collection of meteorological data}

Records of monthly rainfall, temperature and the relative humidity of Jaffna district for the study period (2012-2015) were also obtained from the Meteorological Department, Thirunelvely, Jaffna.

\section{Examination of toddy samples for the presence of amoebic cysts}

Pellets obtained from centrifuged toddy samples were used for microscopic examination and cultured in Robinson's medium [13]. Briefly, pelleted toddy samples were inoculated in the Robinson's medium and incubated at $37{ }^{\circ} \mathrm{C}$ for 48 to $72 \mathrm{~h}$ and checked for motile trophozoites.

\section{Data analysis}

Data were analyzed using SPSS statistical software version 16 and Win Pepi software version 11.62. In addition to describing the characteristics and hygienic practices of the patients admitted to TH Jaffna, randomly selected one hundred male patients were compared in the sub study with 100 male participants who were negative for E. histolytica serum antibody to explore the risk factors. Pearson's, Chi -squared with Yates correction statistical tests were used and odds ratios were calculated to identify the potential risk factors.

\section{Results}

Amoebic liver abscess burden in Jaffna District

In 2012, there were 9 ALA cases per 10,000 total hospital admissions which gradually declined to 3 cases per 10,000 hospital admissions in 2015 (Fig. 1).

\section{Socio-demographic characteristics of the patients}

The condition showed a marked male predominance (98.4\%). The large majority of patients $(94.2 \%)$ were men of the age group 31-50 years. Most of them (77.6\%) had studied up to G.C.E. Ordinary Level (secondary level of education) and the majority (64.5\%) was labourers. Most of them $(86 \%)$ stated that they earned a monthly income of LKR 5000-10,000 (USD 32.74-65.49) (Table 1).

\section{Geographical distribution of the patients}

Patients were more or less equally distributed within the 15 Medical Officers of Health divisions (basic health 


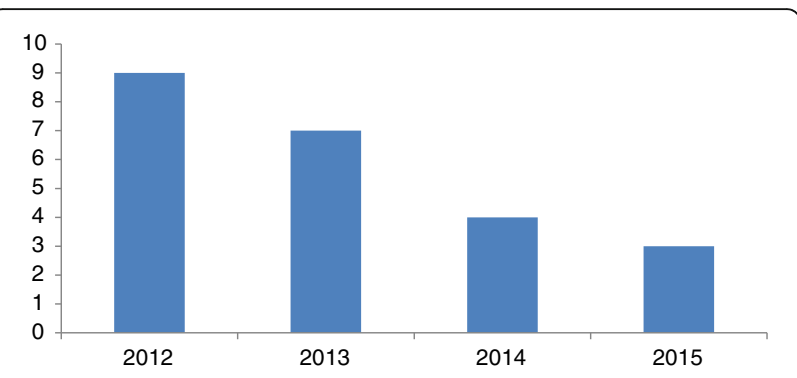

Fig. 1 Number of clinically diagnosed ALA patients per 10,000 admissions at Teaching Hospital, Jaffna

administrative divisions) in Jaffna district and the majority $(75 \%)$ of them was from the rural area.

\section{Personal hygienic practices among the patients}

The majority (93\%) stated that they lived in households with water sealed toilets and most of them (88.4\%) revealed that the distance between the toilet and the drinking water source was roughly about 50 feet (Table 2). However, it was observed there were no latrine facilities in most of the taverns. Further, all reported that they consumed non-purified water and the majority (77.5\%) stated that they occasionally ate food that was not home-cooked. Moreover, most (98.3\%) pointed out that they washed their hands with soap and water after defecation, but, $42.5 \%$ accepted that they rarely washed their hands with soap and water before meals (Table 2). Almost all of them (99.7\%) stated that they cut their nails only rarely or at long intervals (Table 2).

The comparison of hygienic practices among the patients and the control group showed no statistical differences as shown in the Table 2.

\section{Knowledge, attitude and practice towards ALA among the patients}

None of the patients nor the controls had the knowledge of the name of the disease condition, aetiological agent, transmission route, predisposing factors and prevention and control measures. Both the patients and control group (70\% and $80 \%$ respectively) believed that eating well was the way to prevent any liver disease caused by alcohol consumption. Similarly, both groups did not adopt any

Table 1 Socio demographic characteristics of ALA patients admitted to the Teaching Hospital, Jaffna compared with 100 individuals who were E. histolytica serum antibody negative

\begin{tabular}{|c|c|c|c|c|c|}
\hline \multirow[t]{2}{*}{ Variable } & \multirow[t]{2}{*}{ Categories } & \multicolumn{2}{|c|}{ Patients (Cases) } & \multicolumn{2}{|c|}{ E. histolytica serum antibody negative Individuals (controls) } \\
\hline & & $N=346$ & $\%$ with $\mathrm{Cl}$ & $N=100$ & $\%$ with $\mathrm{Cl}$ \\
\hline \multicolumn{6}{|l|}{ Sex } \\
\hline & Male & 341 & 98.6(96.8-99.5) & 100 & 100 \\
\hline & Female & 05 & $1.4(0.5-3.2)$ & 0 & 0 \\
\hline \multicolumn{6}{|l|}{ Age } \\
\hline & $20-30$ & 0 & 0 & 18 & 18(11.4-26.4) \\
\hline & $31-40$ & 110 & $31.8(27.0-36.1)$ & 29 & 29(20.7-38.5) \\
\hline & $41-50$ & 216 & $62.4(57.2-67.4)$ & 23 & $23(15.5-32.0)$ \\
\hline & $51-60$ & 20 & $5.8(3.7-8.6)$ & 30 & $30(21.6-39.5)$ \\
\hline \multicolumn{6}{|c|}{ Educational level } \\
\hline & No school education & 8 & $2.3(1.1-4.3)$ & 2 & $2(0.03-6.5)$ \\
\hline & Up to Grade 8 & 79 & $22.8(18.6-27.5)$ & 24 & 24(16.4-33.1) \\
\hline & Grade 6 to G.C.E O/L & 258 & 77.6(69.8-78.9) & 74 & $74(64.7-81.9)$ \\
\hline & Followed G.C.E O/L & 1 & $0.3(0.000-1.4)$ & 0 & 0 \\
\hline \multicolumn{6}{|c|}{ Occupation } \\
\hline & No Job & 72 & $20.8(16.8-25.3)$ & 5 & $5(1.9-10.7)$ \\
\hline & Labourer & 223 & $64.5(59.3-69.3)$ & 66 & $66(56.3-74.8)$ \\
\hline & Farmer & 33 & $9.5(6.8-13.0)$ & 19 & 19(12.2-27.6) \\
\hline & Fishermen & 17 & $4.9(3.0-7.6)$ & 10 & $10(5.2-17.1)$ \\
\hline & Self employed & 1 & $0.3(0.000-1.4)$ & 0 & 0 \\
\hline \multicolumn{6}{|c|}{ Monthly income } \\
\hline & $<$ LKR5000 (USD 32.76) & 19 & $5.5(3.4-8.3)$ & 3 & $3(0.8-7.9)$ \\
\hline & LKR5000-10000 (USD 32.76-65.49) & 298 & $86.1(82.2-89.5)$ & 87 & 87(79.3-92.6) \\
\hline & LKR10001-LKR 25000 (USD 65.49-163.72) & 29 & $8.4(5.8-11.7)$ & 10 & $10(5.2-17.1)$ \\
\hline
\end{tabular}


Table 2 Personal hygienic practice toward ALA among patients compared with E. histolytica antibody negative (disease free) individuals

\begin{tabular}{|c|c|c|c|c|c|c|}
\hline \multirow[t]{2}{*}{ Variable } & \multirow[t]{2}{*}{ Categories } & \multicolumn{2}{|c|}{ Patients (Cases) } & \multicolumn{2}{|c|}{$\begin{array}{l}\text { E. histolytica serum } \\
\text { antibody negative } \\
\text { Individuals (controls) }\end{array}$} & \multirow[t]{2}{*}{ Statistics } \\
\hline & & $N=346$ & $\%$ with Cl & $N=100$ & $\%$ with Cl & \\
\hline \multirow[t]{3}{*}{ Latrine facilities } & No facility/open air defecation & 3 & $\begin{array}{l}0.9 \\
(0.2-2.3)\end{array}$ & 0 & 0 & \multirow{3}{*}{$\begin{array}{l}\text { Pearson's chi-square } \\
\text { with Yates's } \\
\text { correction }=0.927 \\
P=0.336\end{array}$} \\
\hline & Using pits & 21 & $\begin{array}{l}6.1 \\
(3.9-9.0)\end{array}$ & 3 & $\begin{array}{l}3 \\
(0.8-7.9)\end{array}$ & \\
\hline & Water seal latrine & 322 & $\begin{array}{l}93.1 \\
(90.0-95.4)\end{array}$ & 97 & $\begin{array}{l}97 \\
(92.1-99.2)\end{array}$ & \\
\hline \multirow[t]{2}{*}{$\begin{array}{l}\text { Distance between latrine and } \\
\text { drinking water source }\end{array}$} & roughly $50 \mathrm{ft}$ & 306 & $\begin{array}{l}88.4 \\
(84.7-91.5)\end{array}$ & 86 & $\begin{array}{l}86 \\
(78.1-91.8)\end{array}$ & \multirow{3}{*}{$\begin{array}{l}\text { Pearson's chi-square } \\
\text { with Yates's } \\
\text { correction }=0.235 \\
P=0.628\end{array}$} \\
\hline & $>50 \mathrm{ft}$ & 40 & $\begin{array}{l}11.6 \\
(8.5-15.7)\end{array}$ & 14 & $\begin{array}{l}14 \\
(8.2-21.9)\end{array}$ & \\
\hline Drinking habit & Fresh water & 346 & $\begin{array}{l}100 \\
(99.1-100)\end{array}$ & 100 & $\begin{array}{l}100 \\
(99.1-100)\end{array}$ & \\
\hline \multirow[t]{2}{*}{ Eating habit } & $\begin{array}{l}\text { Rarely eat outside the house } \\
\text { (cafeteria) }\end{array}$ & 78 & $\begin{array}{l}22.5 \\
(18.4-27.2)\end{array}$ & 33 & $\begin{array}{l}33 \\
(24.3-42.6)\end{array}$ & \multirow{2}{*}{$\begin{array}{l}\text { Pearson's chi-square } \\
\text { with Yates's } \\
\text { correction }=3.995 \\
P=0.046\end{array}$} \\
\hline & Sometimes eat in cafeteria & 268 & $\begin{array}{l}77.5 \\
(72.8-81.6)\end{array}$ & 67 & $\begin{array}{l}67 \\
(57.4-75.7)\end{array}$ & \\
\hline \multirow[t]{2}{*}{ Hand washing before eat } & $\begin{array}{l}\text { sometimes wash with soap } \\
\text { and water before eating }\end{array}$ & 199 & $\begin{array}{l}57.5 \\
(52.3-62.7)\end{array}$ & 58 & $\begin{array}{l}58 \\
(48.2-67.4)\end{array}$ & \multirow{2}{*}{$\begin{array}{l}\text { Pearson's chi-square } \\
\text { with Yates's } \\
\text { correction }=0.000 \\
P=1.000\end{array}$} \\
\hline & $\begin{array}{l}\text { Rarely/Not washing hand with } \\
\text { soap and water before eating }\end{array}$ & 147 & $\begin{array}{l}42.5 \\
(37.3-47.7)\end{array}$ & 42 & $\begin{array}{l}42 \\
(32.6-51.8)\end{array}$ & \\
\hline \multirow[t]{2}{*}{ Hand washing after defecation } & sometimes wash with soap and water & 340 & $\begin{array}{l}98.3 \\
(96.4-99.3)\end{array}$ & 98 & $\begin{array}{l}98 \\
(93.5-99.7)\end{array}$ & \multirow{2}{*}{$\begin{array}{l}\text { Pearson's chi-square } \\
\text { with Yates's } \\
\text { correction }=0.000 \\
P=1.000\end{array}$} \\
\hline & rarely/Not washing with soap water & 6 & $\begin{array}{l}1.7 \\
(0.7-3.6)\end{array}$ & 2 & $\begin{array}{l}2 \\
(0.3-6.5)\end{array}$ & \\
\hline \multirow[t]{3}{*}{ Nails cutting habit } & Regularly cutting nails & 1 & $\begin{array}{l}0.3 \\
(0.000-1.4)\end{array}$ & 0 & 0 & \multirow{3}{*}{$\begin{array}{l}\text { T-test (trend test based on } \\
\text { contrasts) [Barlow et al.]: } \\
\text { chi-sq. }=0.267[\mathrm{DF}=1] \\
\text { 2-sided } P=0.605 \text { for trend } \\
\text { in a given direction: } \\
P=0.303\end{array}$} \\
\hline & sometimes cutting nails & 238 & $\begin{array}{l}68.8 \\
(63.8-73.5)\end{array}$ & 68 & $\begin{array}{l}68 \\
(58.4-76.6)\end{array}$ & \\
\hline & cutting nails after a long time & 107 & $\begin{array}{l}30.9 \\
(26.2-35.9)\end{array}$ & 32 & $\begin{array}{l}34 \\
(23.4-41.6)\end{array}$ & \\
\hline
\end{tabular}

particular preventive measures in order to prevent the condition, ALA.

\section{Seasonal variation of the disease}

The monthly incidence of ALA showed the same pattern as the monthly average temperature (Fig. 2) during the study period. The number of cases was high during the dry season compared to the wet or rainy season (Fig. 2). Although the number of cases declined from 2012 to 2015 , each year showed the same pattern of seasonality. At the same time, the relative humidity did not show any pattern with the disease.

\section{Seasonal variation of alcohol consumption}

As shown in Fig. 3, alcohol consumption showed a marked seasonality; specifically median consumption was high in the middle months of the year i.e. in the hot season.

\section{History of alcohol consumption}

All patients (100\%) had a positive history of consumption of alcohol. The majority (79.2\%) were in the habit of consuming toddy and arrack, depending on the money availability. Those who were consuming toddy, consumed palmyrah toddy $(100 \%)$. The majority $(n=$ $245,70.8 \%)$ stated that they consumed alcohol daily (Table 3). As shown in Table 4, among the patients who consumed alcohol daily, $63.7 \%$ and $31.4 \%$ were of the age groups $41-50$ years and $31-40$ years, respectively.

\section{Comparison of some risk factors among patients and control group}

Statistical analysis revealed that age, type of alcohol and frequency of consumption of alcohol was the associated factors for ALA (Table 4). In further analyses (adjusted for age and group of daily consumers and who consumed 4-6 times in a week amalgamated as one group 


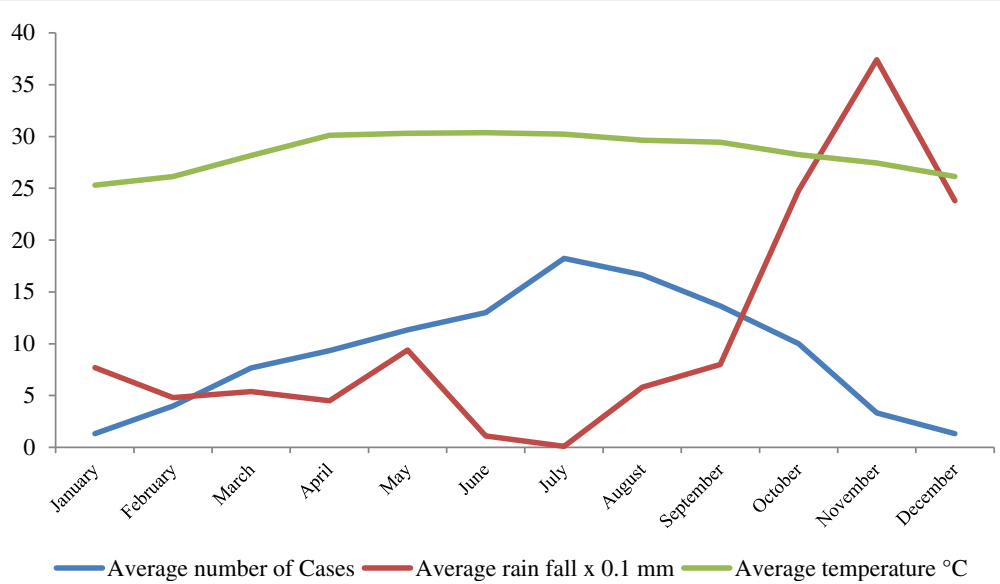

Fig. 2 Comparison of number of cases admitted to the Teaching Hospital, Jaffna, with average monthly climatic data during the study period

and compared with amalgamated group of 2-3 times a week and 2-4 times in month) revealed that the frequency of alcohol consumption (daily consumers and those who consumed 4-6 times a week) (AOR: 701.3, 95\%CI: 103.5 - infinitive) and type of alcohol (toddy and arrack) (OR-4.5, 95\%CI: 1.94-11.96) were the potential risk factors.

\section{Discussion}

Since 1985, ALA has been a public health burden second only to malaria in terms of parasitic infections in Jaffna district (personal communication with the clinicians), northern Sri Lanka. We found that the annual admission rate of ALA in 2012, 2013, 2014, 2015 were 9.0, 7.0, 4.0, and 3.0 per 10,000 total admissions at TH, Jaffna, respectively. Even though a decreasing trend was seen, ALA is still responsible for significant morbidity.

In 1985, the reported rate of ALA at TH, Jaffna was 5.9\% of total hospital admissions [2]. Taken together with the present findings, this indicates that Jaffna has remained persistently endemic. Similarly, Rajasuriya and Nagaratnam [7] reported in 1962 that $1.5 \%$ of total hospital admissions in the General Hospital Colombo were due to ALA, and Ramachandran et al. [8] reported that 3.5\% of total hospital admissions in Negombo Hospital were due to ALA, which

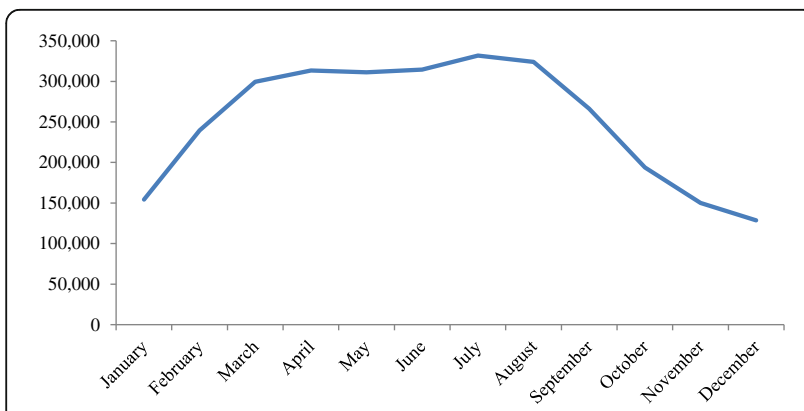

Fig. 3 Monthly mean value of total toddy sold in the district were little lower than that of Jaffna. Although there are no current data available from other parts to compare with our findings, clinicians report that ALA is now rarely seen in other parts of Sri Lanka. Hence, our present findings are more or less in agreement with the study carried out in the same locality [2] 25 years earlier.

Marked male predominance $(98.4 \%)$ was observed in our study as well as in other surveys carried out in Sri Lanka and elsewhere [3-5, 9, 10, 14-28]. This may be due to the differences in alcohol consumption between the two sexes, as well as other contributory factors. Similar patterns have been observed in most countries where amoebiasis is endemic. Where the disease was reported among travellers, and the country is nonendemic, male preponderance was little bit less i.e. 54\% in Spain [27] and 78\% in France [28].

Similarly, the age distribution (31-50) also tallies with reports around the world $[3-5,7,14,17-21,26-28,30]$. Further, frequency of the consumption of alcohol and type of alcohol were identified as the potential risk factors (Table 4). Due to the limitation of small sample size, we were unable to explore the risk factors further. A further, well designed prospective (cohort) study is recommended to explore this finding.

It has been suggested, based on animal models (hamster), that the male hormone testosterone could be a host factor that favours the development of ALA [28]. The positive role of testosterone is one of the explanations that middle-aged men were mostly affected; with increasing age (after 50 years) the incidence declines with the reduction of testosterone levels [28].

Further, it is a well-known fact that iron is a crucial component of E. histolytica enzymes [29]. In vitro experimental studies have showed that iron is a vital growth factor for E. histolytica [30]. Regular menstrual blood loss in females of reproductive age, may lead to lower iron stores [30] which are mainly in the liver [31]. Further, Ralph 
Table 3 Detail description of alcohol consumption habit among ALA patient compared with individual who are E. histolytica antibody negative individuals

\begin{tabular}{|c|c|c|c|c|c|}
\hline \multirow[t]{2}{*}{ Factors } & \multirow[t]{2}{*}{ Category } & \multicolumn{2}{|c|}{ Patients (Cases) } & \multicolumn{2}{|c|}{ E. histolytica serum antibody negative individuals (controls) } \\
\hline & & $N=346$ & $\%$ with $\mathrm{Cl}$ & $N=100$ & $\%$ with Cl \\
\hline Alcohol drinking habit & yes & 346 & $\begin{array}{l}100 \\
(99.1-100)\end{array}$ & 100 & $\begin{array}{l}100 \\
(99.1-100)\end{array}$ \\
\hline \multirow[t]{2}{*}{ Type of alcohol } & Only Toddy & 72 & $\begin{array}{l}20.8 \\
(16.8-25.3)\end{array}$ & 94 & $\begin{array}{l}94 \\
(87.9-97.5)\end{array}$ \\
\hline & Toddy + arrack & 274 & $\begin{array}{l}79.2 \\
(74.7-83.2)\end{array}$ & 6 & \\
\hline Type of toddy & Palmyrah & 346 & $\begin{array}{l}100 \\
(99.1-100)\end{array}$ & 100 & $\begin{array}{l}100 \\
(99.1-100)\end{array}$ \\
\hline \multirow[t]{4}{*}{ Frequency of drinking } & Daily & 245 & $\begin{array}{l}70.8 \\
(65.9-75.4)\end{array}$ & 2 & $\begin{array}{l}6 \\
(2.5-12.1)\end{array}$ \\
\hline & 4-6 times a week & 101 & $\begin{array}{l}29.2 \\
(24.6-34.1)\end{array}$ & 20 & $\begin{array}{l}20 \\
(13.0-28.7)\end{array}$ \\
\hline & 2-3 times a week & 0 & 0 & 10 & $\begin{array}{l}10 \\
(5.2-17.1)\end{array}$ \\
\hline & 2-4 times a month & 0 & 0 & 68 & $\begin{array}{l}68 \\
(58.4-76.6)\end{array}$ \\
\hline
\end{tabular}

Warren and John Kempston [32] have also proposed that alcoholic hepato-cellular damage in males and the protective effect is mainly due to the iron deficient anaemia or protective hormonal factors in women of child bearing age. However, alcohol consumption may be lower among females due to cultural reasons. Interestingly, in our study, the few females who had ALA also had a history of consuming toddy.

Makkar et al. [30] have suggested that high content of iron and a diet rich in carbohydrate in habitual consumers of alcohol may predispose to invasive amoebiasis, leading to ALA. Further, age predilection and gender bias in the formation of ALA is also based on the high alcohol intake [18].

Apart from age and sex, the other associated risk factor identified in our study was consumption of alcohol (100\%). A majority of the researchers working on ALA have reported the habit of alcohol consumption, particularly in endemic areas [3-5, 10, 14-21].

The percentage of patients who consumed alcohol varied from $50 \%$ in Bangladesh [10] to $100 \%$ in Jaffna, Sri Lanka [5]. Our previous findings (100\%) in this locality still stand in this regard [5].

Ghosh et al. [18] have reported that alcohol suppresses the function of Kupffer cells in the liver which has the important role in clearing the amoeba.

Further, Raja and Karthick [16] suggested that the invasive capacity of E. histolytica is facilitated by alcohol which is harmful to the liver and by nutritional deficiencies in alcoholics, thus leading to a higher incidence of ALA in alcoholics. Further, they reported that duration and quality of alcohol consumed also play an important role in the higher incidence of liver abscess

Table 4 Comparison of significantly differing factors between ALA patients and E. histolytica antibody negative individuals

\begin{tabular}{|c|c|c|c|c|}
\hline \multirow[t]{2}{*}{ Factors } & \multirow[t]{2}{*}{ Category } & \multicolumn{2}{|c|}{ E. histolytica serum Antibody (lgG) } & \multirow[t]{2}{*}{ Statistics } \\
\hline & & $\begin{array}{l}\text { Positive } \\
\text { (cases) } N=100\end{array}$ & $\begin{array}{l}\text { Negative } \\
\text { (Control) } N=100\end{array}$ & \\
\hline \multirow[t]{4}{*}{ Age group } & $21-30$ yrs & 0 & 18 & \multirow[t]{4}{*}{ Chi- Square-56.63; Df-3; $P<0.001$} \\
\hline & $31-40$ yrs & 29 & 29 & \\
\hline & $41-50$ yrs & 66 & 23 & \\
\hline & $51-60$ yrs & 5 & 30 & \\
\hline \multirow[t]{2}{*}{ Type of alcohol } & Only toddy & 27 & 94 & \multirow[t]{2}{*}{ Chi- square- 99.92; Df-1; $\mathrm{P}<0.001, \mathrm{OR}-4.5,95 \% \mathrm{Cl}: 1.94-11.96$} \\
\hline & Toddy + Arrack & 73 & 6 & \\
\hline \multirow[t]{4}{*}{ Frequency of drinking } & Daily & 70 & 2 & \multirow[t]{4}{*}{ Chi Squre-1.481Ea Df-3 $P<0.0001$} \\
\hline & 4-6 times a week & 30 & 20 & \\
\hline & 2-3 times a week & 0 & 10 & \\
\hline & 2-4 times a month & 0 & 68 & \\
\hline
\end{tabular}


and therefore alcoholism is the most important predisposing factor [16].

Meanwhile, Mukhopadhyay et al. [17] suggested that alcohol can predispose to ALA in the following manner, a) hepatic damage by alcohol, b) habitual consumers often neglect meals resulting in lowered body resistance and suppression of liver function, c) liquor prepared locally with no regard for asepsis has a large population of amoeba in it and d) immunity in chronic alcoholics is depressed. In an earlier report, Hai et al. [9] reported the involvement of toddy in predisposing to ALA, but noted that the mechanism was unclear. On the contrary, Siddiqui et al. [10] argued that indigenous alcohol has much more association with the development of pyogenic liver abscess. Meanwhile, Ramachandran [33] and Fernando et al. [3] strongly believed toddy was the medium for the transmission of E. histolytica.

At the same time, Raja and Karthick [16] further reported that though alcoholism seems to be the predisposing factor, it has no role in the aetiology.

Further, Makkar et al. [30] also disagree with the statement that "toddy becomes susceptible because of the large dose of E. histolytica ingested with the drink". They argued that ALA seems to be common in alcoholics irrespective of the type of alcohol used.

In our study too, we were unable to demonstrate the infective stage of $E$. histolytica from toddy. Further, we found that $79 \%$ of the patients consumed toddy as well as arrack depending on the money availability which was found as an independent risk factor.

We found that the peak of the disease was correlated with the dry seasons (Fig. 2). The number of cases increased from March up to July and started to decline until September. A similar finding was observed in a study carried out last year in India [11], where they have reported that the transmission predominantly occurred late summer to early rainy seasons.

There is a belief among the consumers that the toddy has a cooling effect on the body during the hot dry season. Therefore, this may be the reason for increased intake of toddy during the dry season and for the increasing rate of the disease which was further supported by the increased sales of toddy during the dry season.

\section{Conclusion}

Though the number of cases has declined in recent years, amoebic liver abscess still remains an important public health problem in Jaffna district, northern Sri Lanka. Middle aged males who reported heavy consumption of alcohol, and lived mainly in rural areas, were mostly affected by this condition. The incidence was highest in the dry season. Statistical analysis showed the type of alcohol and the frequency of consumption to be the potential risk factors. However, none of the toddy samples demonstrated Entamoeba histolytica cysts. Hence, establishing the route of transmission of the parasite is of great importance. Moreover, all patients and controls were found lacking in knowledge, attitude and practice towards ALA. Therefore, conducting awareness programs through mass media and community level to the public who are at risk is essential, in order to eliminate the disease.

\section{Additional file}

Additional file 1: English language version of the questionnaire. The English language version of the questionnaire used to collect the following information a) general socio demographic data b) personal hygienic practices and alcohol consumption history and c) the knowledge, attitude and practices in relation to ALA. (DOCX $18 \mathrm{~kb}$ )

\section{Abbreviations \\ ALA: Amoebic liver abscess; AOR: Adjusted odds ratio; Cl: Confidence interval; Df: Degrees of freedom; G.C.E O/L: General certificate of education ordinary level; KAP: Knowledge, attitude and practice; LKR: Sri Lankan rupees; OR: Odds ratio; SPSS: Statistical package for the social sciences; TH: Teaching hospital}

\section{Acknowledgments \\ The authors thank the participants (patients and volunteers) of this study, the Director, all the consultants, clinicians, Medical Officers, and nursing staff attached to the Teaching hospital, Jaffna for their permission and assistance to carry out this study. Further they thank the Regional Director of Health Services, Jaffna for providing the total admission data at $\mathrm{TH}$, Jaffna, and the Excise Department for the total toddy sales information in addition to the Metrological Department, Thirunelvely, Jaffna for the climatic data.}

\section{Funding}

This study was financially supported by the HRD program of HETC project (JFN /O-Med/ N8) by the World Bank. The funders had no role in study design, collection, analysis and interpretation of data, and preparation of the manuscript.

\section{Availability of data and materials}

The dataset is available from the corresponding author on reasonable request. The English language version of the questionnaire developed specifically for use in this study can be found as the supplementary file (see Additional file 1).

\section{Authors' contributions}

SK, AM, NRS, DI and RH conceived the study. SK and TK involved in the data and sample collection. NR did analysis. SK, NR and NRS wrote the manuscript. All authors read and approved the manuscript.

\section{Ethics approval and consent to participate}

Ethical clearance was obtained from the Ethical Review Committee of the Faculty of Medicine, University of Jaffna. Permission to carry out this study was obtained from the Director, TH, Jaffna and written consent was obtained from the participants after explaining the purpose and the nature of the study.

\section{Consent for publication}

Not applicable as there is no individual data in any form.

\section{Competing interests}

The authors declare that they have no competing interests.

\section{Publisher's Note}

Springer Nature remains neutral with regard to jurisdictional claims in published maps and institutional affiliations. 


\section{Author details}

'Department of Pathology, Faculty of Medicine, University of Jaffna, Jaffna, Sri Lanka. ${ }^{2}$ Department of Medicine, Faculty of Medicine, University of Jaffna, Jaffna, Sri Lanka. ${ }^{3}$ Department of Parasitology, Faculty of Medicine, University of Kelaniya, Ragama, Sri Lanka. 'St Johns' Park Medical Center, Sydney, Australia. International Centre for Diarrhoeal Disease Research, Dhaka, Bangladesh. ${ }^{6}$ Department of Parasitology, Faculty of Medicine, University of Peradeniya, Peradeniya, Sri Lanka.

Received: 24 July 2017 Accepted: 5 January 2018

Published online: 10 January 2018

\section{References}

1. World Health Organization World Health Organization. Pan American health organization/UNESCO report of a consultation of expert on Amoebiasis. Wkly Epidemiol Rec. 1997;72:97-9.

2. Sreeharan NMD, Yogeswaran $P$, Puthrasingam S, Ranjadayalan $K$ Ganeshamoorthy J. Hepatic amoebiasis in northern Sri Lanka: a retrospective study. Jaffna Med J. 1985;20(2):69-74.

3. Fernando $K$, Fernando R, Kandasami A, Jude R, Fernando N, Tennakoon S. SP6-3 fermented sap of spiky Palmyra toddy (Borassus flabellifer) suggested as a vehicle of transportation of amoebiasis in the district of Mannar, Sri Lanka: 50 cases of amoebic liver abscess within 15 months. J Epidemiol Commun H. 2011:65(1):455.

4. Janani T, Pushpana P, Surenthirakumaran R, Kumanan T, Kannanthasan S Amoebic liver abscess: an emerging threat in northern Sri Lanka. In: EMBO global lecture course and symposium on amoebiasis: Exploring the biology and pathogenesis of Entamoeba. March 4-7. India: Khajuraho; 2011. p. 80.

5. Kannathasan S, Iddawala WMDR, Silva NR De, Haque R: Knowledge, attitude and practice towards liver abscess among patients admitted to the teaching hospitals, Jaffna. Proc of the Peradeniya Univ Int Res Sessions, Sri Lanka. 2014; 18: 355

6. Kannathasan S, Murugananthan A, Kumanan T, et al. Amoebic liver abscess in northern Sri Lanka: first report of immunological and molecular confirmation of aetiology. Parasit Vectors. 2017;10:14. https://doi.org/10. 1186/s13071-016-1950-2.

7. Rajasuriya K, Nagaratnam N. Hepatic amoebiasis in Ceylon. J Trop Med Hyg. 1962;65(7):165-78.

8. Ramachandran S, Sivalingam S, Perumal JRA. Hepatic amoebiasis in Ceylon. J Trop Med Hyg. 1972;75:23-33.

9. Hai AA, Singh A, Mittal VK, Karan GC. Amoebic liver abscess. Review of 220 cases. Int Surg. 1990;76(2):81-3.

10. Siddiqui MA, Ahad MA, Ekram AS, Islam QT, Hoque MA, Masum QAAI. Clinico-pathological profile of liver abscess in a teaching hospital. TAJ: J Teachers Assoc. 2008;21(1):44-9.

11. Prasad VS, Subrahmanyam M. Prevalence of amoebic liver abscess in relation to season, age and sex. J Evid Based Med. 2015;2(17):2592-5.

12. Takeuchi T, Okuzawa E, Nozaki T, Kobayashi S, Mizokami M, Minoshima N, et al. High seropositivity of Japanese homosexual men for amoebic infection. J Infect Dis. 1989;159(808):10-1093.

13. Robinson GL. Laboratory diagnosis of some human parasitic amoeba. J Gen Microbiol. 1968:53:69-79.

14. Alam F, Salam MA, Hassan P, Mahmood I, Kabir M, Haque R. Amoebic liver abscess in northern region of Bangladesh: sociodemographic determinants and clinical outcomes. BMC Res Notes. 2014;7(1):625.

15. Chaudhary S, Noor MT, Jain S, Kumar R, Thakur BS. Amoebic liver abscess: a report from central India. Trop Dr. 2015; 1177/0049475515592283

16. Raja CS, Karthick P. Role of alcoholism in liver abscess. Int J Res Med Sci. 2014;2:1313-9

17. Mukhopadhyay M, Saha AK, Sarkar A, Mukherjee S. Amoebic liver abscess: presentation and complications. Indian J Surg. 2010;72(1):37-41.

18. Ghosh S, Sharma S, Gadpayle AK, Gupta HK, Mahajan RK, Sahoo R, Kumar N. Clinical, laboratory, and management profile in patients of liver abscess from northern India. J Trop Med. 2014; https://doi.org/10.1155/2014/142382

19. Sharma N, Sharma A, Varma S, Lal A, Singh V. Amoebic liver abscess in the medical emergency of a north Indian hospital. BMC Res Notes. 2010;3(21):1-4.

20. Lodhi S, Sarwari AR, Muzammil M, Salam A, Smego RA. Features distinguishing amoebic from pyogenic liver abscess: a review of 577 adult cases. Tropical Med Int Health. 2004;9(6):718-23.
21. Congly SE, Shaheen AAM, Meddings L, Kaplan GG, Myers RP. Amoebic liver abscess in USA: a population-based study of incidence, temporal trends and mortality. Liver Int. 2011;31(8):1191-8.

22. Sharma MP, Ahuja V. Amoebic liver abscess. J Indian Acad. Clin Med. 2003; 4(2):107-11

23. Giorgio A, Esposito V, Farella N, Di Sarno A, Liorre G, De Stefano M, et al. Amoebic liver abscesses: a new epidemiological trend in a non-endemic area? In vivo. 2009;23(6):1027-30.

24. Acuno-Soto R, Maguire JH, Wirth DF. Gender distribution in asymptomatic and invasive amoebiasis. Am J Gastro enterol. 2000;95(5):1227-83.

25. Alvi AR, Rizvi F, Kazim SF, Ejaz K, Zafar H, Chawla T, et al. Amoebic liver abscess: experience in a south Asian country. Trop Dr. 2010;40(1):39-40.

26. Blessmann J, Pham Van L, Anthon NP, Duong Thi H, Muller- Myhsok B, Buss H, Tannich E. Epidemiology of amoebiasis in a region of high incidence of amoebic liver abscess in central Vietnam. Am J Trop Med Hyg. 2002;66(5):578-83.

27. Cosme A, Ojeda E, Zamarreño I, Bujanda L, Garmendia G, Echeverría MJ, Benavente J. Pyogenic versus amoebic liver abscesses. A comparative clinical study in a series of 58 patients. Rev Esp Enferm Dig. 2010;102(2):90-5.

28. Cordel H, Prendki V, Madec Y, Houze S, Paris L, et al. Imported amoebic liver abscess in France. PLoS Negl Trop Dis. 2013;7(8):e2333. https://doi.org/10. 1371/ journal.pntd.0002333.

29. Ortíz-Estrada G, Luna-Castro S, Piña-Vázquez C, Samaniego-Barrón L, LeónSicairos N, Serrano-Luna J, De La Garza M. Iron-saturated lactoferrin and pathogenic protozoa: could this protein be an iron source for their parasitic style of life? Future Microbiol. 2012;7(1):149-64.

30. Makkar RP, Sachdev GK, Malhotra V. Alcohol consumption, hepatic iron load and the risk of amoebic liver abscess: a case-control study. Internal Med. 2003;42(8):644-9.

31. Powell LW. Normal human iron storage and its relation to ethanol consumption. Aust. Ann Med. 1966;15:110-5.

32. Warren $\mathrm{R}$, Kempston J. A review of amoebic liver abscess for clinicians in a nonendemic setting. Can J Gastro enterol. 2012;26(10):729.

33. Ramachandran S. Hepatic amoebiasis. The Marcus Fernando memorial oration 1974. Ceylon Med J. 1975;20:69-81.

\section{Submit your next manuscript to BioMed Central and we will help you at every step:}

- We accept pre-submission inquiries

- Our selector tool helps you to find the most relevant journal

- We provide round the clock customer support

- Convenient online submission

- Thorough peer review

- Inclusion in PubMed and all major indexing services

- Maximum visibility for your research

Submit your manuscript at www.biomedcentral.com/submit 